\title{
Effect of Ultrahigh Frequency Radiation Emitted from 2G Cell Phone on Developing Lens of Chick Embryo: A Histological Study
}

\author{
Mary Hydrina D’Silva, ${ }^{1}$ Rijied Thompson Swer, ${ }^{1}$ J. Anbalagan, ${ }^{1}$ and Rajesh Bhargavan ${ }^{2}$ \\ ${ }^{1}$ Department of Anatomy, Mahatma Gandhi Medical College \& Research Institute (MGMC\&RI), \\ Cuddalore-Pondy Main Road, Pillaiyarkuppam, Puducherry 607402, India \\ ${ }^{2}$ Department of Anatomy, Sri Lakshminarayana Institute of Medical Sciences (SLIMS), Bharath University, \\ Puducherry 605502, India
}

Correspondence should be addressed to Mary Hydrina D’Silva; hydriswer@gmail.com

Received 12 June 2014; Revised 30 August 2014; Accepted 4 September 2014; Published 17 September 2014

Academic Editor: Marius Raica

Copyright (C) 2014 Mary Hydrina D’Silva et al. This is an open access article distributed under the Creative Commons Attribution License, which permits unrestricted use, distribution, and reproduction in any medium, provided the original work is properly cited.

\begin{abstract}
A Mobile phone in operation emits a pulsed radiofrequency electromagnetic field which is absorbed into the user's body particularly the head region. Contradictory scientific reports on the health effect of nonionizing radiations on biological tissues have prompted to undertake the present study to evaluate the damage in the developing lens of a chick embryo following exposure to radiation emitted from a $2 \mathrm{G}$ cell phone. Fertilized chick embryos were incubated in two groups in a standard egg incubator. The experiment group was exposed to radiation emitted from a $2 \mathrm{G}$ cell phone. On completion of scheduled duration, the embryos were collected and processed for routine histological studies. The 9th to 12th day chick embryo eyes were processed for assessment of DNA damage using the alkaline comet assay technique. The lens thickness and the equatorial diameter were measured using oculometer and statistically compared for both groups. In the present study, the exposure of chick embryos to a $2 \mathrm{G}$ cell phone caused structural changes in lens epithelial cells, formation of cystic cells and spaces, distortion of lens fibers, and formation of posterior aberrant nuclear layer. The DNA damage in the developing eyes of the experiment group assessed by comet assay was highly significant.
\end{abstract}

\section{Introduction}

Cell phones have revolutionized the wireless telecommunications industry over the past decade. It has made telecommunication faster, convenient, and more economical. The advancement in mobile phone technology with multifunctional features has attracted more cell phone users, both young and old, throughout the world with 6 billion GSM/2G cell phone users at present. This growing demand has given rise to the installment of more base stations to send and receive communication signals. These wireless telecommunication devices operate with the help of radio frequency (RF) fields just like TV, radio, radar, and microwave oven. Various scientific reports on the possible health hazards on the long term effects of radiofrequency radiation emitted from the cell phone have caused a lot of public concern.
RF radiations emitted from cell phones are usually absorbed by the user's body, especially in the head region as the handsets are held against the ear. Since the eye is in close proximity to this radiation field, a number of researches have been conducted on both human and animal models to find the possible effects of RF radiations emitted from cell phone on the eyes. RF radiation has been reported to cause both thermal and nonthermal effects in the body. According to ICNRP (International Commission on Nonionizing Radiation Protection) guidelines, the microwave exposure limit for eyes is set at $5 \mathrm{~mW} / \mathrm{cm}^{2}$. Exposure levels below this will not produce any thermal stress and could be tolerated by the body through stress-management mechanisms without any possible damage. But in most of the scientific studies, exposure levels well within the set limit also have shown cell 
damage in the lens and retina probably due to nonthermal effects of microwaves on the eye.

Several contradictory reports are posted on the effect of exposure of the chick embryo retina to cell phone radiation. Exposure increased the body growth and retinal differentiation up to 10th day followed by retarded growth on further exposure [1]. Zareen et al. [2] reported a decreased retinal differentiation up to the 10th day followed by growth enhancement on further exposure. Khaki et al. [3] reported an increase in the retinal thickness of rats exposed to electromagnetic fields for 4 weeks.

Bormusov et al. [4] exposed cultured bovine lens to RF radiation that resulted in structural changes in lens epithelial cell and enzyme activities. Dovrat et al. [5] reported impaired optical function of the bovine lens due to damage of lens fibers after RF exposure. RF radiation on rabbit lens showed various biochemical changes in the form of altered protein expression on cell membranes of lens epithelial cells, which declined cell proliferation, and lens epithelial cells damage and opacity [6-8]. The heat shock proteins, HSP-70 and HSP27 , in lens epithelial cells $[9,10]$ are reported to increase due to radiation exposure. Oxidative stress is a leading cause for cataractogenesis. Studies on animal models have shown that RFR exposure caused deformation of heat labile enzyme glutathione peroxidase that protects lens cell proteins and membrane lipids from oxidative damage [11]. The structural damages are in the form of granular degeneration of the lens cell epithelium at the equator, appearance of large spherical or ovoid "balloon cells," smaller cells with condensed nuclei, and damaged cytoplasm with pyknosis $[4,5,12]$.

$\mathrm{RF}$ radiation emitted per cell phone enhances the activity of free radicals in the cells by Fenton reaction. These free radicals damage the DNA, leading to single strand breaks (SSB) and double strand breaks (DSB) [13]. DNA strand breaks are also caused by various exogenous factors such as $\mathrm{UV}$, ionizing and nonionizing radiation, and chemicals [14]. Phillips et al. [15] exposed Molt-4 human lymphoblastoid cells to low intensity EMF from TDMA and i DEN cell phone for 2-21 hrs. Their study showed both increased and decreased DNA damage, depending on the type of signal, intensity, and duration of exposure. Diem et al. [16] reported that the intermittent exposure schedule caused significantly more DNA damage than continuous exposure. Studies on human lens epithelial cells in exposing to $1.8 \mathrm{GHz}$ at SAR of 3 and $4 \mathrm{~W} / \mathrm{Kg}$ field showed increased SSB and irreversible DNA damage $[9,17]$. The exposure of human lens epithelial cells (HLEC) to microwaves of $1800 \mathrm{MHz}$ resulted in repairable DNA damage $[9,18]$. However, some studies have shown absence of DNA damage in human lymphocyte and leukocyte culture on exposure to RFR emitted from cell phone [1921] and in rat brain exposed to $915 \mathrm{MHz}$ GSM microwaves $[22,23]$.

Organogenesis period is regarded as the most critical phase in the dynamic process of development of an embryo. The external and internal environmental insult during this period could result in an adverse outcome. Exposure of chick embryos to RF radiations resulted in increased mortality rate [24-28] and development of numerous congenital anomalies $[1,29]$. The present study is made to evaluate the possible effect of RF radiation emitted from 2G/GSM mobile phones on developing chick embryo lens.

\section{Materials and Methods}

Fertile hen eggs (gallus domesticus) were procured from Rajiv Gandhi College of Veterinary and Animal Sciences, Puducherry. The eggs were incubated in 10 batches of 12 eggs each (a total of 120 eggs) in a standard egg incubator at $37 \pm$ $0.5^{\circ} \mathrm{C}$ with $50-55 \%$ of humidity and ventilation. The eggs were rotated manually 4 times a day and checked periodically with a candler for the viability of the embryos.

The first 5 batches (60 eggs) were treated as control and next 5 batches (60 eggs) as experiment group was exposed to RFR from a $2 \mathrm{G}$ cell phone operating in a frequency range of $900-1800 \mathrm{MHz}$ and SAR of 2.0 watts/kilogram. The experiment group was incubated with the cell phone hung from above with $5 \mathrm{~cm}$ distances separating the egg with head phones plugged in to ensure that the cell phone gets switched on automatically each time it gets a call. The control group was also incubated with the cell phone kept in a nonoperational mode in null status.

For exposure, the cell phone was rung from another cell phone for a duration of 3 minutes each, every half an hour, with the first exposure delivered at 12th hour of incubation $(4.30 \mathrm{am}-4.30 \mathrm{pm})$. The total exposure for a 12-hour period was 72 minutes, followed by 12 hours of exposure-free period. This was repeated daily. Six embryos per day were sacrificed from the 5th to 12th day for the first 4 batches of both the groups. Their weight and gross morphological features were recorded. The embryos were fixed in 10\% formalin and then processed for routine histological studies. The 5 micron thick sections were cut in sagittal, coronal, and transverse planes and stained with $\mathrm{H} \& \mathrm{E}$ and PAS stain. The transverse diameter and thickness of the lens were measured using oculometer. The values obtained for control and experiment group were statistically analyzed using the student $t$-test with SPSS 22 version software.

The 5th batch of chick embryo eyes of both groups $(12+$ 12) were used to assess the DNA damage using alkaline comet assay technique developed by Singh et al. [30] with modifications in staining procedure [31]. The eyes were removed and minced in Hanks Balanced Salt Solution (HBSS). The cell suspension was used for the assay. The slides were stained with silver nitrate and then analyzed using automated comet scoring software (Comet Score IV) to assess and quantify the levels of DNA damage in both groups. The mean comet length, the mean tail length, mean \% of DNA in the tail, and mean tail moment of both groups were statistically compared using unpaired $t$-test with Graph Pad Instat 3.

\section{Observations}

In the present study, an increased mortality rate and congenital anomalies among the experiment group of 5th-9th days were observed. There was no mortality in 10-12th-day experiment group and the morphological features appeared normal. 
The lens of the fifth day control group showed normal features with single layered lens epithelial cells and lens fibers arranged regularly without any spaces between them. The nuclei were elongated in lens epithelial cells. In experiment group, spaces between lens fibers and multilayered lens epithelium were observed.

In the sixth day control embryo, the nuclei of the lens fibers were densely packed at the equator and the nuclei of the inner fibers were displaced anteriorly giving the bow lens appearance as "c"/"s" shaped curve (Figure 3). However, most of the lenses of experiment group showed extensive damage in the form of spaces between lens fibers with multilayered cells (Figure 4).

Lens of 7th day control embryos showed normal features. The experiment group lens appeared double layer and multilayered. The lens fibers showed fragmentation with cystic spaces and at some places the lens fibers have swollen to form cystic cells/balloon cells (Figure 5). In the central part of the lens, the nuclei appeared small and spherical. In the anterior part of the lens, the nuclei are elongated and arranged in the form of lens bow and posteriorly the lens fibers showed the irregular orientation with spaces (Figure 5).

The lens of 8th-day control embryos showed regularly arranged lens fibers with elongated nuclei concentrating towards the equator and they showed lens bow appearance. The experiment group lens showed mainly double layered/multilayered lens epithelial layer and small, elongated condensed nuclei at the periphery. Towards the center of the lens, the nuclei were small and spherical and less dense. Cystic spaces and cells were found to be largely towards anterior part. Few experiment embryos showed a wrinkled capsule on the posterior part (Figure 6) and an aberrantly formed posterior epithelium (Figure 7).

Lens fibers of 9th-12th day experiment embryos showed changes in the form of cystic spaces and cystic cells with small nuclei and variance in lining epithelium from stratified instead of single layered epithelium (Figures 8 and 9). The control embryos showed normal structural features (Figure 10).

The thickness of lens in both control and experimental group showed a gradual increase as the incubation period progressed. The lens thickness of 5th-10th day experiment group was higher when compared to control group (Table 1). However, lens thickness of 11th and 12th day experiment group was less when compared to the control group of same age (Figure 1).

The equatorial diameter of both control and experimental embryo showed a gradual increase as the age advanced. When compared between the groups, the experimental embryo lens showed an increased equatorial diameter than the control group (Table 2, Figure 2).

Our study showed an extremely significant increase in the mean comet length, the mean tail length, mean $\%$ of DNA in the tail, and mean tail moment in the eyes of the experimental group (Table 3). They further showed moderate to severe DNA damage (Figure 11) when compared to the control group that showed minimal damage (Figure 12). The damage was maximum on the 9th day and minimum on the 12th day for the experimental group.

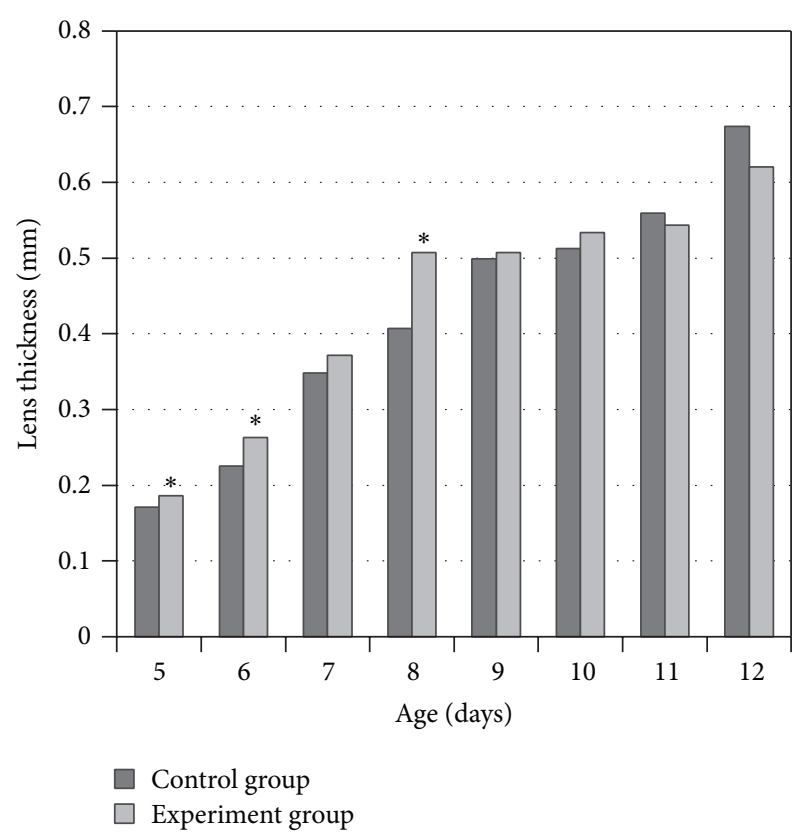

FIGURE 1: Graph showing the effect of electromagnetic fields from a $2 \mathrm{G}$ cell phone on the lens thickness. Values are means \pm SE taken from 6 samples per day for control and experiment group (total sample size of 48 embryos each for control group and experiment group). “*” represents $P$ value statistically significant.

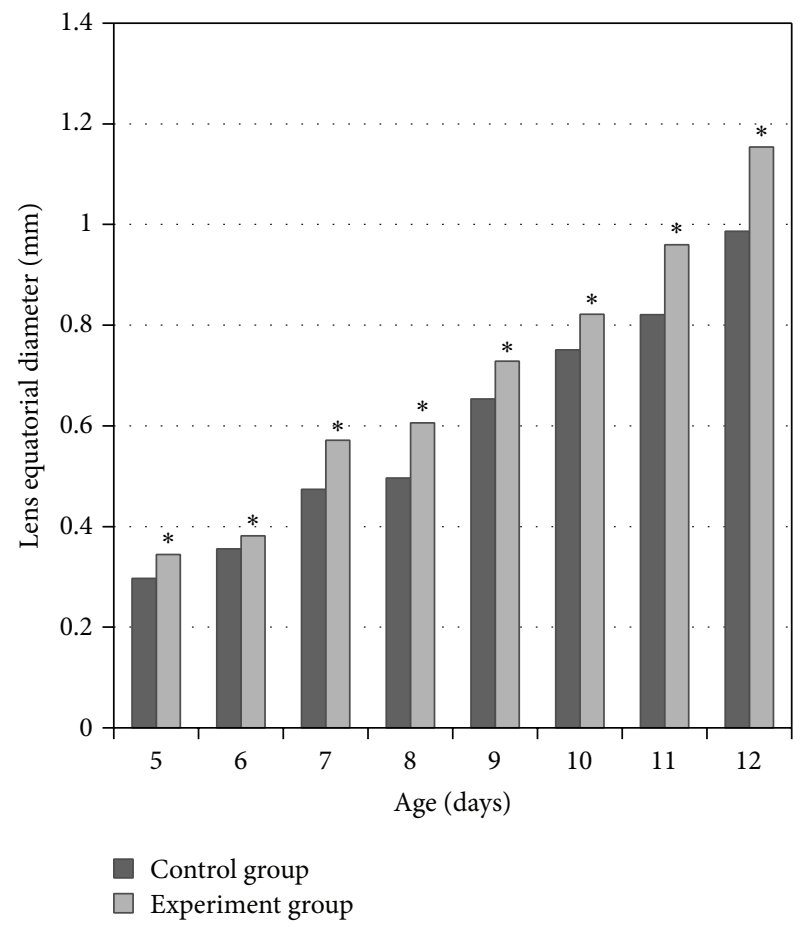

FIGURE 2: Graph showing the effect of electromagnetic fields from $2 \mathrm{G}$ cell phone on the lens equatorial diameter. Values are means \pm SE taken from 6 samples per day for control and experiment group (total sample size of 48 embryos each for control group \& experiment group). “*” represents $P$ value statistically significant. 
TABLE 1

\begin{tabular}{|c|c|c|}
\hline \multirow{2}{*}{ Age in days } & \multicolumn{2}{|c|}{ Mean lens thickness in $\mathrm{mm}$} \\
\hline & Control group & Experiment group \\
\hline 5 & 0.1712 & $0.1866^{*}$ \\
\hline 6 & 0.2254 & $0.2633^{* * *}$ \\
\hline 7 & 0.3486 & 0.3716 \\
\hline 8 & 0.4072 & $0.5073^{* * *}$ \\
\hline 9 & 0.4992 & 0.5077 \\
\hline 10 & 0.5125 & 0.5338 \\
\hline 11 & 0.5593 & 0.5439 \\
\hline 12 & 0.6737 & 0.6202 \\
\hline
\end{tabular}

$\left(P\right.$ value $<0.05^{*}$ significant, $<0.01$ highly significant, and $<0.001^{* * *}$ extremely significant).

TABLE 2

\begin{tabular}{lcc}
\hline Age in days & \multicolumn{2}{c}{ Mean lens equatorial diameter $(\mathrm{mm})$} \\
Control group & Experiment group \\
\hline 5 & 0.2971 & $0.3441^{*}$ \\
6 & 0.3553 & $0.3814^{* * *}$ \\
7 & 0.4735 & $0.5717^{* * *}$ \\
8 & 0.4967 & $0.6058^{* * *}$ \\
9 & 0.6531 & $0.7285^{* * *}$ \\
10 & 0.7509 & $0.8216^{* *}$ \\
11 & 0.8211 & $0.9597^{* * *}$ \\
12 & 0.9866 & $1.1541^{* * *}$ \\
\hline$\left(P\right.$ value $<0.05^{*}$ significant, $<0.01^{* *}$ highly significant, and $<0.001^{* * *}$ \\
extremely significant).
\end{tabular}

\section{Discussion}

An electromagnetic radiation emitted from a cell phone is a known environmental stress factor and could affect the dynamic developmental process of an embryo.

$\mathrm{RF}$ radiation emitted per cell phone caused damaging effects in the form of increased mortality rate and various congenital anomalies. Al-Qudsi and Azzouz [1] and Lahijani and Ghafoori [29] reported the development of abnormal brain ventricles, anophthalmia, spina bifida, abdominal hernia, and growth retardation in chick embryos exposed to RF radiation from GSM mobile phone. In our present study, RF exposure from $2 \mathrm{G}$ phone caused subcutaneous hemorrhage, anophthalmia, monophthalmia, microophthalmia, limb bud anomalies, development of conjoint embryos, and growth retardation.

The mortality rate was $16.6 \%$ in the experiment group and was significantly less in the control group (8.33\%). Earlier studies also reported an increased mortality rate ranging from 52 to $77.78 \%$ in chick embryos exposed to RF radiation from cell phones [24-28].

As a known teratogen, RF radiations from cell phone have a negative impact on the developing lens of the chick embryo. It is regarded as a risk factor in the formation of cataract $[32,33]$. Ocular lens has a unique cellular architecture with 2 types of cells. It consists of a single layer of lens epithelial cells (LECs) on the anterior surface that undergoes mitosis

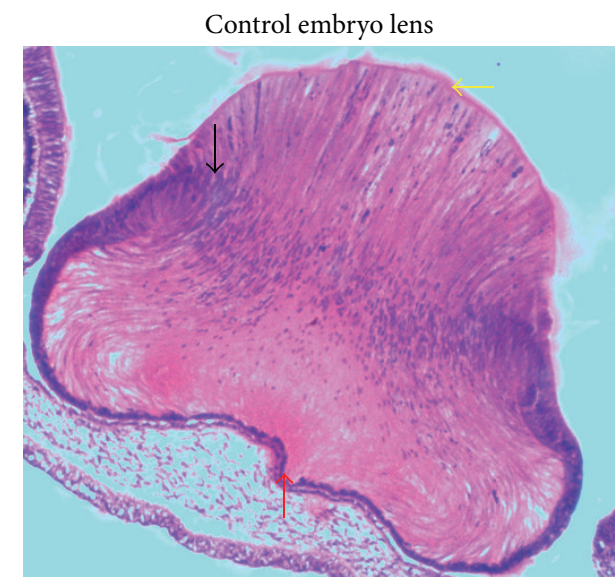

FIgURE 3: Photomicrograph of 7-day-old control embryo lens showing single layered epithelium on anterior surface (red arrow), lens bow arrangement of nuclei near the equator (black arrow), and lens capsule (yellow arrow). $\mathrm{H} \& \mathrm{E} \times 100$.

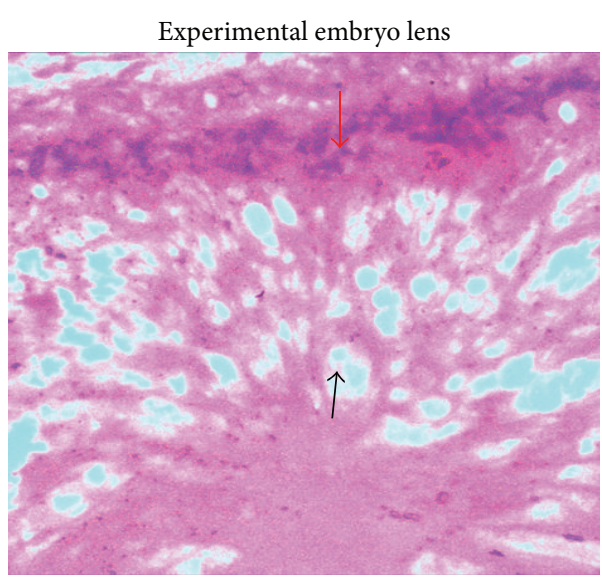

FIGURE 4: Photomicrograph of 8-day-old experimental embryo lens showing lens epithelial cells which is multilayered having pyknotic nuclei (red arrow) and cystic spaces in anterior subcapsular cortex (black arrow). H\&E $\times 400$.

and forms lens fiber cells that migrate posteriorly forming the main bulk of the lens. The lens capsule makes up the basement membrane of lens epithelium.

In the present study, the lens epithelial cells of the control embryos were single on the anterior surface extending towards the equator. Lens fiber cells were elongated and closely packed with flattened elongated nuclei. The nuclei of these lens fibers showed a characteristic forward arch in the form of "C" or "S" shaped curve (lens bow appearance) due to the deposition of successive generations of lens fibers (Figure 3).

However, experiment group embryos showed structural changes. Lens epithelial cells were the first cells exposed to $\mathrm{RF}$ radiation and bear the maximum insult. Thus experiment groups lens epithelium was multilayered on its anterior surface [34] and cystic spaces appeared between the lens fibers [12] (Figures 4 and 8). From 7th day onwards, the 
TABLE 3

\begin{tabular}{lcccccccc}
\hline \multirow{2}{*}{ Age in days } & \multicolumn{2}{c}{ Mean comet length $(\mu \mathrm{m})$} & \multicolumn{2}{c}{ Mean tail length $(\mu \mathrm{m})$} & \multicolumn{2}{c}{ \% of DNA in tail $(\mu \mathrm{m})$} & \multicolumn{2}{c}{ Mean tail moment $(\mu \mathrm{m})$} \\
& CON & EXP & CON & EXP & CON & EXP & CON & EXP \\
\hline 9 & 6.95 & $8.8^{* * *}$ & 5.85 & $7.29^{* * *}$ & 34.69 & $42.91^{*}$ & 174.7 & $286.18^{* * *}$ \\
10 & 6.90 & $8.56^{* * *}$ & 5.19 & $6.66^{* * *}$ & 27.71 & $43.64^{* * *}$ & 131.77 & $256.61^{* * *}$ \\
11 & 4.36 & $7.27^{* * *}$ & 2.84 & $6.009^{* * *}$ & 27.82 & $34.40^{*}$ & 71.11 & $174.97^{* * *}$ \\
12 & 6.5 & 7.15 & 4.82 & 5.3 & 24.71 & $35.23^{* * *}$ & 108.73 & $170.83^{* *}$ \\
\hline
\end{tabular}

$\left(P\right.$ value $<0.05^{*}$ significant, $<0.01^{* *}$ highly significant, and $<0.001^{* * *}$ extremely significant $)$.

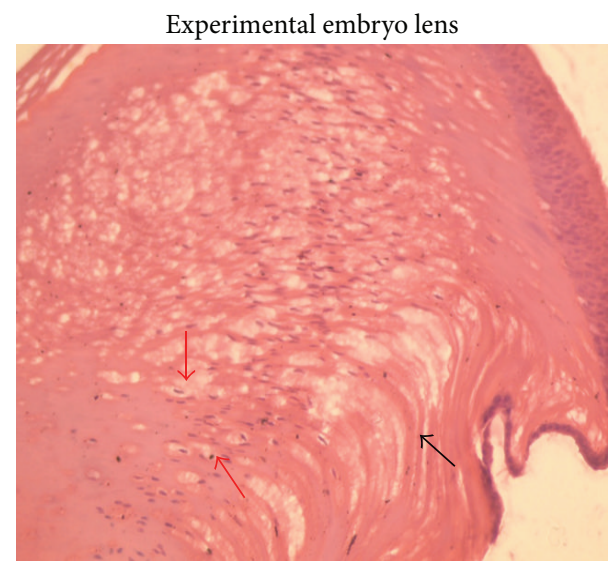

FIgURE 5: Photomicrograph of 10-day-old experimental embryo lens showing distorted arrangement of lens fibres (black arrow) and cystic cells and spaces in lens cortex (red arrow) $\mathrm{H} \& \mathrm{E} \times 400$.

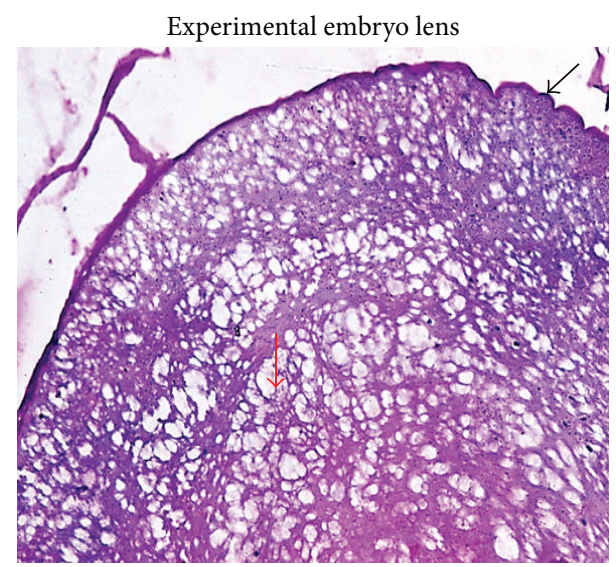

Figure 6: Photomicrograph of 10-day-old experimental embryo lens showing wrinkled posterior lens capsule (black arrow) and cystic spaces in posterior subcapsular cortex (red arrow) PAS $\times 400$.

experiment group showed extensive damage with epithelial cells at the equator swelling up to form "cystic cells" or "balloon cells". These pathological cells increased in number and size as the incubation period progressed (Figures 4, 5, 6,8 , and 9 ). This was probably due to an abortive attempt of epithelial cells to undergo normal differentiation into new lens fibers [12]. In the experiment group, the lens bow appearance was found to be distorted with displacement of nuclei more posteriorly and distorted lens fibers appeared

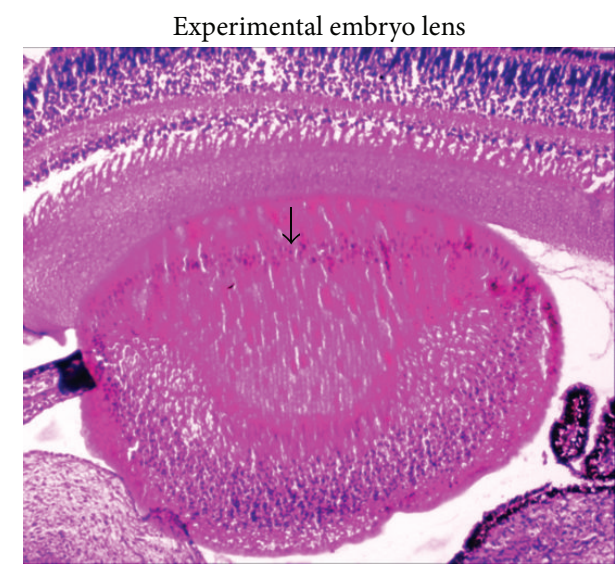

FIgURE 7: Photomicrograph of 11-day-old experimental embryo lens showing posterior displacement of aberrant nuclear layer (arrow). $\mathrm{H} \& \mathrm{E} \times 100$.

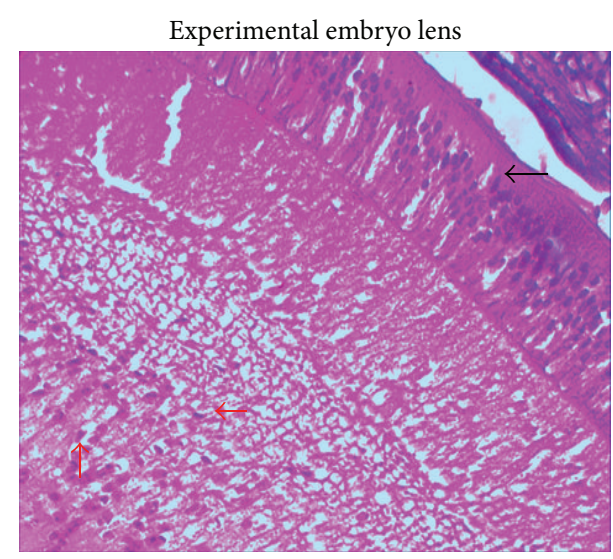

FIGURE 8: Photomicrograph of 11-day-old experimental embryo lens showing multilayered lens epithelium (black arrow) and cystic cells and spaces (red arrow). $\mathrm{H} \& \mathrm{E} \times 400$.

towards the posterior part due to swelling of posterior ends of lens fibers (Figure 5). The appearance of aberrantly formed epithelium on the posterior surface may be due to increased mitotic activity and migration of epithelial cells induced by $\mathrm{RF}$ radiation [6,12] (Figure 8). The appearance of smaller lens epithelial cells with condensed pyknotic nuclei and damaged cytoplasm was similar to the findings reported by Bormusov et al. [4]. 


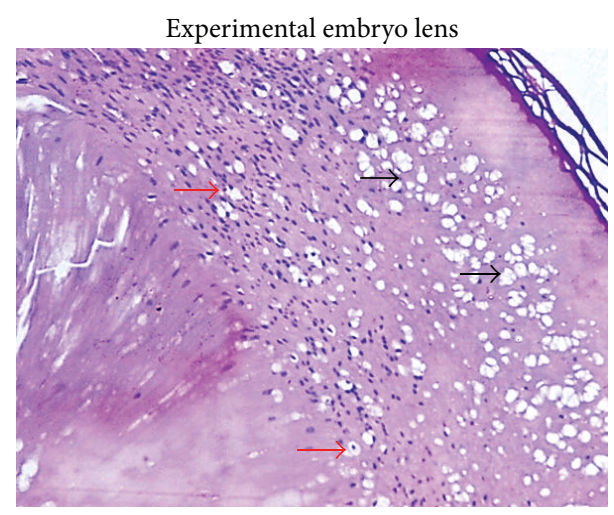

FIGURE 9: Photomicrograph of 12-day-old experimental embryo lens showing cystic cells (red arrow) and spaces (black arrow). PAS stain $\times 400$.

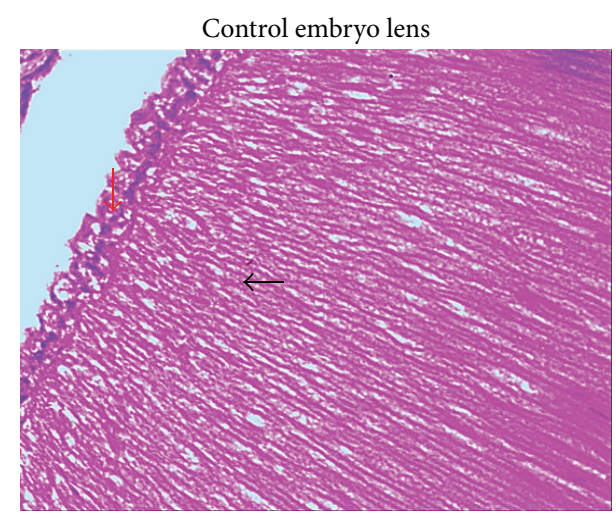

FIgURE 10: Photomicrograph of 12-day-old control embryo lens showing single layered epithelium on anterior surface (red arrow) and regularly arranged lens fibres (black arrow) $\mathrm{H} \& \mathrm{E} \times 400$.

Development is a dynamic process consisting of a highly ordered sequence of cell proliferation, differentiation, migration, and programmed cell death [2]. These events are based on endogenous ionic currents and electric fields present in the cells. These fields get disrupted due to RF radiations from the cell phone that in turn affect these processes [2]. In the present study, the formation of multilayered epithelium on the anterior surface of the experiment lens and aberrantly formed posterior epithelium was probably due to the increased cell proliferation of lens epithelial cells due to $2 \mathrm{G}$ cell phone radiation exposure.

Ocular lens is a nonvascularized, noninnervated tissue containing high percentage of water. Owing to its poor blood supply, it lacks the ability to dissipate heat. This along with the high percentage of water makes ocular lens highly sensitive to RF radiation [8]. Moreover, lens fiber cells have limited capacity for repair and fibers towards the center have less metabolic activity. The proteins present in these fibers do not turn over significantly and they are extremely long lived and vulnerable to oxidative stress [34].

RF radiation causes irreversible morphological and biochemical changes in LEC [4] affecting normal functioning.
Bormusov et al. [4] reported apoptotic changes, reduction in cell size, decreased mitochondria, and appearance of a balloon shaped mitochondria. Ye et al. [35] observed a reduction in connexin 43 expression intercellular gap junctions disrupting the coordinated transport activity in LECs and inhibited delivery of ions and nutrients to lens fiber cells. Regulation of ion and water content of lens fibers is essential to maintain its structural integrity, optical homogeneity, and transparency [34]. RF exposure also caused unfolding of protein structure, exposing the sulfhydryl groups. These groups may engage in disulphide bonding which results in further cross-linking and conformation changes [34] leading to cataract.

Oxidative stress is a leading cause for cataractogenesis. In the present study, the histopathological changes observed were similar to those of cortical cataract [36] produced by an ionizing radiation [37, 38]. Cystic cells and vacuolations were reported to be present mainly in the lenticular fibers beneath the posterior capsule in radiation cataract $[37,38]$ (Figure 6). Nevertheless, in the present study, they were seen even in the anterior subcapsular cortex (Figure 4) correlating the findings of Carpenter [12].

In the present study, the mean thickness and equatorial diameter of the lens increased as the incubation period was prolonged in both control and experiment group. The mean thickness of the 5th, 6th, and 8th day experiment embryos showed a significant increase $(P$ value $<0.04,<0.001$, and $<0.00007$, resp.) in comparison with the control group. However, 7th, 9th, and 10th day experiment embryos showed an insignificant increase in mean lens thickness. The mean thickness of the 11th and the 12th day control embryo lens was slightly more than that of the same age experiment group and was statistically insignificant. The equatorial diameters of the lens of the experiment group were higher in comparison with the same age control embryo lens $(P$ value $<0)$. This increase in equatorial diameter may probably be due to RF exposure resulting in proliferation of LECs to form secondary lens fibers. The increased proliferation of these cells also resulted in multilayered epithelium on the anterior surface and formation of aberrant posterior epithelial layer on the posterior surface. Increased equatorial diameter of experiment lens might also be due to the formation of large sized cystic cells and their consequent increase as the age advanced. The LECs proliferate throughout the life which is important for maintaining metabolic homeostasis and transparency [8].

RF radiation impairs oxidant/antioxidant balance in the LECs which in turn affects normal functioning of LECs [9$11,39,40]$. Moreover, RF radiation causes production of free radicals by means of Fenton reaction [13] which kill cells by damaging macromolecules such as DNA, protein, and membrane. These secondary changes in the cells on exposure to $\mathrm{RF}$ radiation impair DNA repair mechanism that results in DNA damage. The DNA damage is seen in the form of DNA strand breaks and DNA cross links [14]. There are two types of DNA strand breaks: single strand breaks (SSB) and double strand breaks (DSB). DSB is more lethal. DNA strand breaks are associated with cell death, aging, and cancer. 


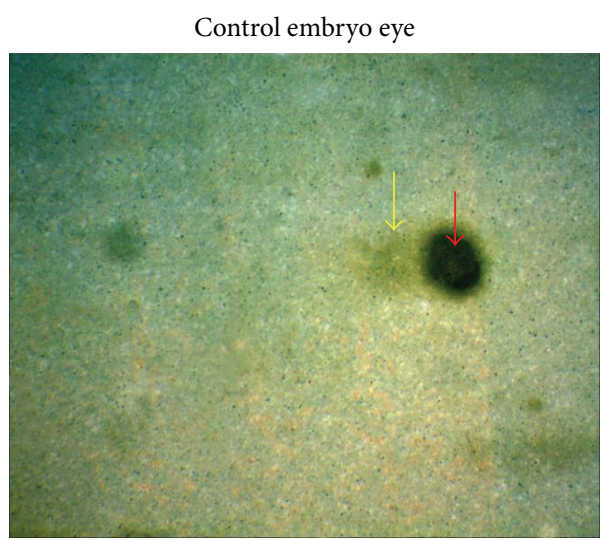

(a)

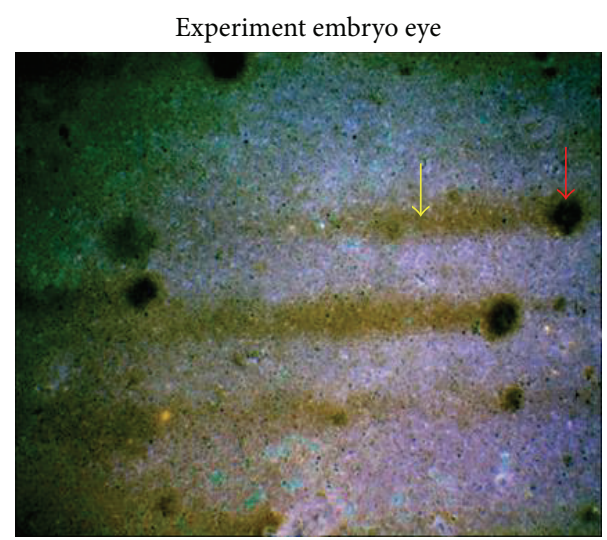

(b)

FIgURE 11: (a) Photomicrograph of 9 day old control embryo comets showing minimal DNA damage. Head diameter is large (red arrow) and tail length is shorter (yellow arrow) 10X. (b) Photomicrograph of 9-day-old experiment embryo comets showing severe DNA damage. Head diameter is decreased (red arrow) and tail length is increased (yellow arrow).

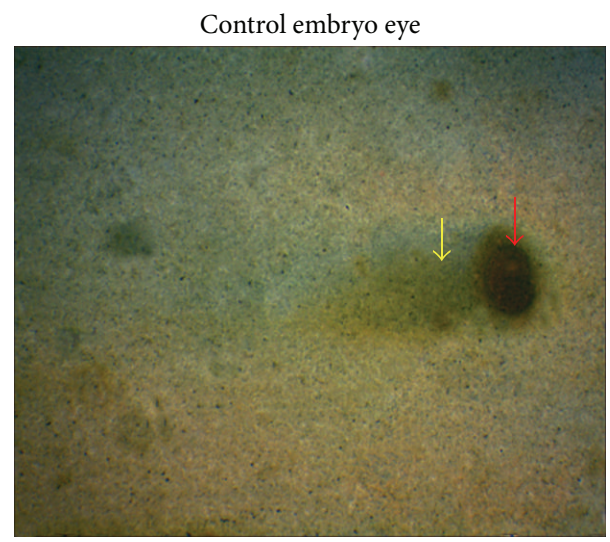

(a)

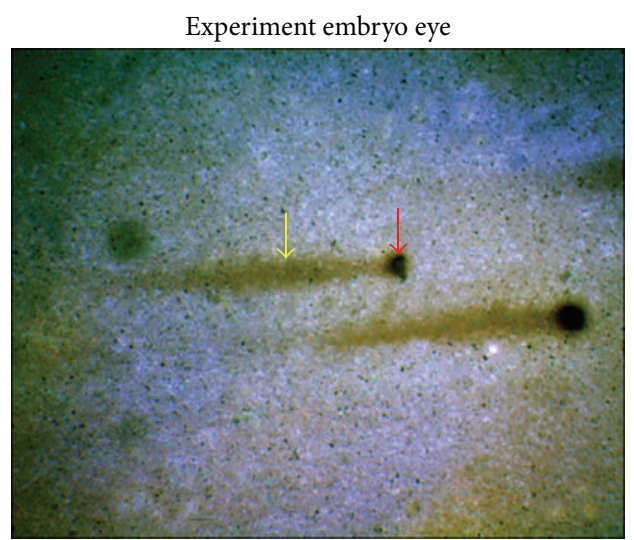

(b)

FIGURE 12: (a) Photomicrograph of 11 day old control embryo comets showing minimal DNA damage. Head diameter is large (red arrow) and tail length is shorter (yellow arrow) 10X. (b) Photomicrograph of 11-day-old experiment embryo comets showing severe DNA damage. Head diameter is decreased (red arrow) and tail length is increased (yellow arrow). 10x.

In the present study, we have assessed the DSB in the developing eyes of the chick embryo following chronic exposure to $\mathrm{RF}$ radiation from a $2 \mathrm{G}$ cell phone using the alkaline comet assay. Our study showed significantly increased DNA damage in the experiment group as compared with control group (Table 3). The damage was seen in the form of increased mean comet length, mean tail length, mean $\%$ of DNA in the tail, and mean tail moment in 9th-11th day experiment group (Figures 11 and 12). The mean comet length and the mean tail length of both groups on 12th day did not show significant change but mean \% of DNA in tail and mean tail moment showed an increase in experimental group which was highly significant (Table 3). Our study also observed an increased DNA damage on the 9th day and a reduction in the intensity of DNA damage on a 12th day experimental group. This decreased damage is probably due to the protective mechanism of LEC by activating enzyme pathways to protect its components from oxidative stress and maintain homeostasis [41].
Different types of cells in our body respond differently to the EMF. Metabolically active cells, cells having a high level of intracellular free iron, cells having fewer amounts of antioxidants and antioxidative enzymes, and so forth are more susceptible to DNA damage $[13,14]$. Cancer cells and cells that undergo abnormal proliferation have a high concentration of free iron because they uptake more iron and have less efficient iron storage regulation $[13,14]$. Iron catalyzes the conversion of hydrogen peroxide formed due to oxidative respiration into hydroxyl ions that are very potent and toxic free radicals that damage the DNA (Fenton reaction). In our study, also abnormal proliferation of lens epithelial cells would have resulted in increased DNA damage in the eye of experiment group by the same mechanism.

\section{Conclusion}

The present study showed that exposure of developing chick embryo lens to RF radiation from a $2 \mathrm{G}$ cell phone resulted 
in micro structural changes in the lens. These changes were observed as multilayered epithelium on the anterior surface of lens, formation of aberrant posterior epithelium, cystic cells and spaces, and distortion in the arrangement of posterior part of lens fibers. Such changes were reported in the lens exposed to ionizing radiation. In addition to that, the RF radiation also caused an increase in the mean equatorial diameter of lens due to increased proliferation of lens epithelial cells. The anomalous proliferation of LEC caused by $\mathrm{RF}$ radiation from $2 \mathrm{G}$ cell phone also made these cells more susceptible to DNA damage in the form of DSB. The damage was seen in the form of increased mean comet length, the mean tail length, mean \% of DNA in the tail, and mean tail moment. Whether these anomalous proliferation and DSB could lead to uncontrolled neoplastic cellular proliferation requires further experimental study.

\section{Disclosure}

The Undersigned authors hereby declare that the paper "Effect of ultrahigh frequency radiation emitted from $2 \mathrm{G}$ cell phone on developing lens of chick embryo: a histological study" has been read and approved and the work has been carried out in the department of Anatomy, MGMC\&RI under our supervision. The authors warrant that the paper is original and is not under consideration by any other journal and has been previously published and has taken responsibility for the context. Furthermore, they warrant that all investigations reported in their publication were conducted in conformity with the recommendation from the Declaration of Helsinki and the international guiding principles for biomedical research involving animals.

\section{Conflict of Interests}

The authors state that they have no conflict of interests regarding the publication of this paper.

\section{Acknowledgments}

The authors express their sincere thanks to Mr. Lokesh Maran, statistician, Dr. S. Arunchandra Singh, Head of the department of Anatomy, and Dr. Sudha Rao, professor of Anatomy of Mahatma Gandhi Medical College and Research Institute, Puducherry, for their valuable suggestions and support, thus making this study possible.

\section{References}

[1] F. Al-Qudsi and S. Azzouz, "Effect of electromagnetic mobile radiation on chick embryo development," Life Science Journal, vol. 9, no. 2, pp. 983-991, 2012.

[2] N. Zareen, M. Khan, and L. Minhas, "Derangement of chick embryo retinal differentiation caused by radiofrequency electromagnetic fields," Congenital Anomalies, vol. 49, no. 1, pp. 1519, 2009.

[3] A. A. Khaki, M. R. Sedghipour, A. A. Milani, L. Roshangar, J. S. Rad, and M. Nijad, "Study on ultrastructural and morphometric effects of electromagnetic fields (EMF) on retina of rat," Medical
Journal of Tabiz university of medical sciences, vol. 33, no. 1, pp. 18-24, 2011.

[4] E. Bormusov, U. Andley, N. Sharon, L. Schächter, A. Lahav, and A. Dovrat, "Non-thermal electromagnetic radiation damage to lens epithelium," The Open Ophthalmology Journal, vol. 2, pp. 102-106, 2008.

[5] A. Dovrat, R. Berenson, E. Bormusov et al., "Localized effects of microwave radiation on the intact eye lens in culture conditions," Bioelectromagnetics, vol. 26, no. 5, pp. 398-405, 2005.

[6] K. Yao, K. J. Wang, Z. H. Sun et al., "Low power microwave radiation inhibits the proliferation of rabbit lens epithelial cells by upregulating P27Kip1 expression," Molecular Vision, vol. 10, pp. 138-143, 2004.

[7] J. Ye, K. Yao, D. Lu, R. Wu, and G. H. Jian, "Low power density microwave radiation induced early changes in rabbit lens epithelial cells," Chinese Medical Journal, vol. 114, no. 12, pp. 1290-1294, 2001.

[8] Y. Yu and K. Yao, "Non-thermal cellular effects of low-power microwave radiation on the lens and lens epithelial cells," Journal of International Medical Research, vol. 38, no. 3, pp. 729736, 2010.

[9] S. Lixia, K. Yao, W. Kaijun et al., "Effects of $1.8 \mathrm{GHz}$ radiofrequency field on DNA damage and expression of heat shock protein 70 in human lens epithelial cells," Mutation Research, vol. 602, no. 1-2, pp. 135-142, 2006.

[10] Y. Yu, K. Yao, W. Wu, K. Wang, G. Chen, and D. Lu, "Effects of exposure to $1.8 \mathrm{GHz}$ radiofrequency field on the expression of Hsps and phosphorylation of MAPKs in human lens epithelial cells," Cell Research, vol. 18, no. 12, pp. 1233-1235, 2008.

[11] R. Bernat, "Glutathione concentration and peptidase activity in the lens after exposure to microwaves." Acta physiologica Polonica, vol. 36, no. 5-6, pp. 360-365, 1985.

[12] R. L. Carpenter, "Ocular effects of microwave radiation," Bulletin of the New York Academy of Medicine, vol. 55, no. 11, pp. 1048-1057, 1979.

[13] H. Lai and N. P. Singh, "Single- and double-strand DNA breaks in rat brain cells after acute exposure to radiofrequency electromagnetic radiation," International Journal of Radiation Biology, vol. 69, no. 4, pp. 513-521, 1996.

[14] J. L. Phillips, N. P. Singh, and H. Lai, "Electromagnetic fields and DNA damage," Pathophysiology, vol. 16, no. 2-3, pp. 79-88, 2009.

[15] J. L. Phillips, O. Ivaschuk, T. Ishida-Jones, R. A. Jones, M. Campbell-Beachler, and W. Haggren, "DNA damage in molt-4 T-lymphoblastoid cells exposed to cellular telephone radiofrequency fields in vitro," Bioelectrochemistry and Bioenergetics, vol. 45, no. 1, pp. 103-110, 1998.

[16] E. Diem, C. Schwarz, F. Adlkofer, O. Jahn, and H. Rüdiger, "Non-thermal DNA breakage by mobile-phone radiation (1800 $\mathrm{MHz}$ ) in human fibroblasts and in transformed GFSH-R17 rat granulosa cells in vitro," Mutation Research: Genetic Toxicology and Environmental Mutagenesis, vol. 583, no. 2, pp. 178-183, 2005.

[17] L. X. Sun, K. Yao, J. L. He, D. Q. Lu, K. J. Wang, and H. W. Li, "Effect of acute exposure to microwave from mobile phone on DNA damageand repair of cultured human lens epithelial cells in vitro," Zhonghua Lao Dong Wei Sheng Zhi Ye Bing Za Zhi, vol. 24, pp. 465-467, 2006.

[18] K. Yao, W. Wu, K. J. Wang et al., "Electromagnetic noise inhibits radiofrequency radiation-induced DNA damage and reactive oxygen species increase in human lens epithelial cells," Molecular Vision, vol. 14, pp. 964-969, 2008. 
[19] B. Z. Leal, M. Szilagyi, T. J. Prihoda, and M. L. Meltz, "Primary DNA damage in human blood lymphocytes exposed in vitro to $2450 \mathrm{MHz}$ radiofrequency radiation," Radiation Research, vol. 153, no. 4, pp. 479-486, 2000.

[20] R. R. Tice, G. G. Hook, M. Donner, D. I. McRee, and A. W. Guy, "Genotoxicity of radiofrequency signals. I. Investigation of DNA damage and micronuclei induction in cultured human blood cells," Bioelectromagnetics, vol. 23, no. 2, pp. 113-126, 2002.

[21] O. Zeni, M. Romanò, A. Perrotta et al., "Evaluation of genotoxic effects in human peripheral blood leukocytes following an acute in vitro exposure to $900 \mathrm{MHz}$ radiofrequency fields," Bioelectromagnetics, vol. 26, no. 4, pp. 258-265, 2005.

[22] L. Verschaeve, P. Heikkinen, G. Verheyen et al., "Investigation of co-genotoxic effects of radiofrequency electromagnetic fields in vivo," Radiation Research, vol. 165, no. 5, pp. 598-607, 2006.

[23] I. Y. Belyaev, C. B. Koch, O. Terenius et al., "Exposure of rat brain to $915 \mathrm{MHz}$ GSM microwaves induces changes in gene expression but not double stranded DNA breaks or effects on chromatin conformation," Bioelectromagnetics, vol. 27, no. 4, pp. 295-306, 2006.

[24] F. Batellier, I. Couty, D. Picard, and J. P. Brillard, "Effects of exposing chicken eggs to a cell phone in "call" position over the entire incubation period," Theriogenology, vol. 69, no. 6, pp. 737$745,2008$.

[25] M. Bastide, B. J. Youbicier-Simoa, J. C. Lebecq, and J. Giaimis, "Toxicologic study of electromagnetic radiation emitted by television and video display screens and cellular telephones on chickens and mice," Indoor and Built Environment, vol. 10, no. 5, pp. 291-298, 2001.

[26] G. Iug, "Biological effects of mobile phone electromagnetic field on chick embryo (risk assessment using the mortality rate)," Radiation Biology, Radioecology and Dosimetry, vol. 43, no. 5, pp. 541-543, 2003.

[27] I. V. Ingole and S. K. Ghosh, "Exposure to radio frequency radiation emitted by cell phone and mortality in chick embryos (Gallus domesticus)," Biomedical Research, vol. 17, no. 3, pp. 205-210, 2006.

[28] K. Saito, K. Suzuki, and S. Motoyoshi, "Lethal and teratogenic effects of long-term low-intensity radio frequency radiation at $428 \mathrm{MHz}$ on developing chick embryo," Teratology, vol. 43, no. 6, pp. 609-614, 1991.

[29] M. S. Lahijani and M. Ghafoori, "Teratogenic effects of sinusoidal extremely low frequency electromagnetic fields on morphology of 24 hr chick embryos," Indian Journal of Experimental Biology, vol. 38, no. 7, pp. 692-699, 2000.

[30] N. P. Singh, M. T. McCoy, R. R. Tice, and E. L. Schneider, "A simple technique for quantitation of low levels of DNA damage in individual cells," Experimental Cell Research, vol. 175, no. 1, pp. 184-191, 1988.

[31] B. Rajesh, "Detection of level of DNA damage in petrol pump attendants of Puducherry union territory through Comet Assay," DSTE-Project Report 93, Department of Science, Technology \& Environment, Pondicherry, India, 2014, http:// dste.puducherry.gov.in/DSTE_Final_report-Dr.Rajesh.pdf.

[32] R. M. Lipman, B. J. Tripathi, and R. C. Tripathi, "Cataracts induced by microwave and ionizing radiation," Survey of Ophthalmology, vol. 33, no. 3, pp. 200-210, 1988.

[33] A. Cutz, "Effects of microwave radiation on the eye: the occupational health perspective," Lens and Eye Toxicity Research, vol. 6, no. 1-2, pp. 379-386, 1989.

[34] A. J. Bron, R. C. Tripathi, and B. J. Tripathi, Wolff's Anatomy of the Eye and Orbit, 8th edition, 1998.
[35] J. Ye, K. Yao, Q. Zeng, and D. Lu, "Changes in gap junctional intercellular communication in rabits lens epithelial cells induced by low power density microwave radiation," Chinese Medical Journal, vol. 115, no. 12, pp. 1873-1876, 2002.

[36] I. Damjanov and J. Linder, Anderson's Pathology, vol. 2, CRC Press, 10th edition, 1995.

[37] T. Tokunaga, "Histopathological findings in radiation cataract," Japanese Journal of Clinical Ophthalmology, vol. 17, pp. 587-592, 1963.

[38] S. J. Kimura and H. Ikui, "Atomic-bomb radiation cataract. Case report with histopathologic study," The American Journal of Ophthalmology, vol. 34, no. 6, pp. 811-816, 1951.

[39] M. Balci, E. Devrim, and I. Durak, "Effects of mobile phones on oxidant/antioxidant balance in cornea and lens of rats," Current Eye Research, vol. 32, no. 1, pp. 21-25, 2007.

[40] G. Jelodar, A. Akbari, and S. Nazifi, "The prophylactic effect of vitamin $\mathrm{C}$ on oxidative stress indexes in rat eyes following exposure to radiofrequency wave generated by a BTS antenna model," International Journal of Radiation Biology, vol. 89, no. 2, pp. 128-131, 2013.

[41] V. M. Berthoud and E. C. Beyer, "Oxidative stress, lens gap junctions, and cataracts," Antioxidants and Redox Signaling, vol. 11, no. 2, pp. 339-353, 2009. 

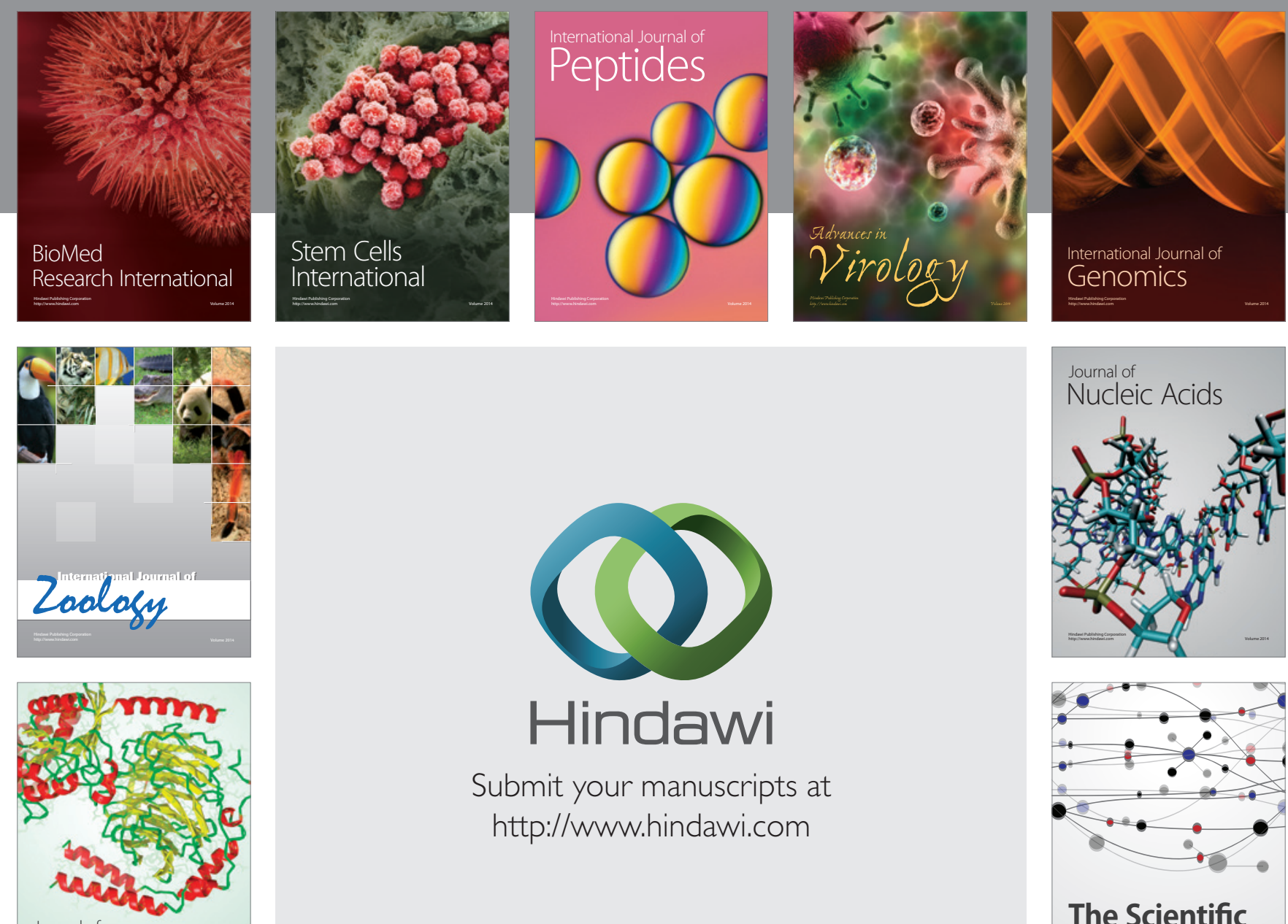

Submit your manuscripts at

http://www.hindawi.com

Journal of
Signal Transduction
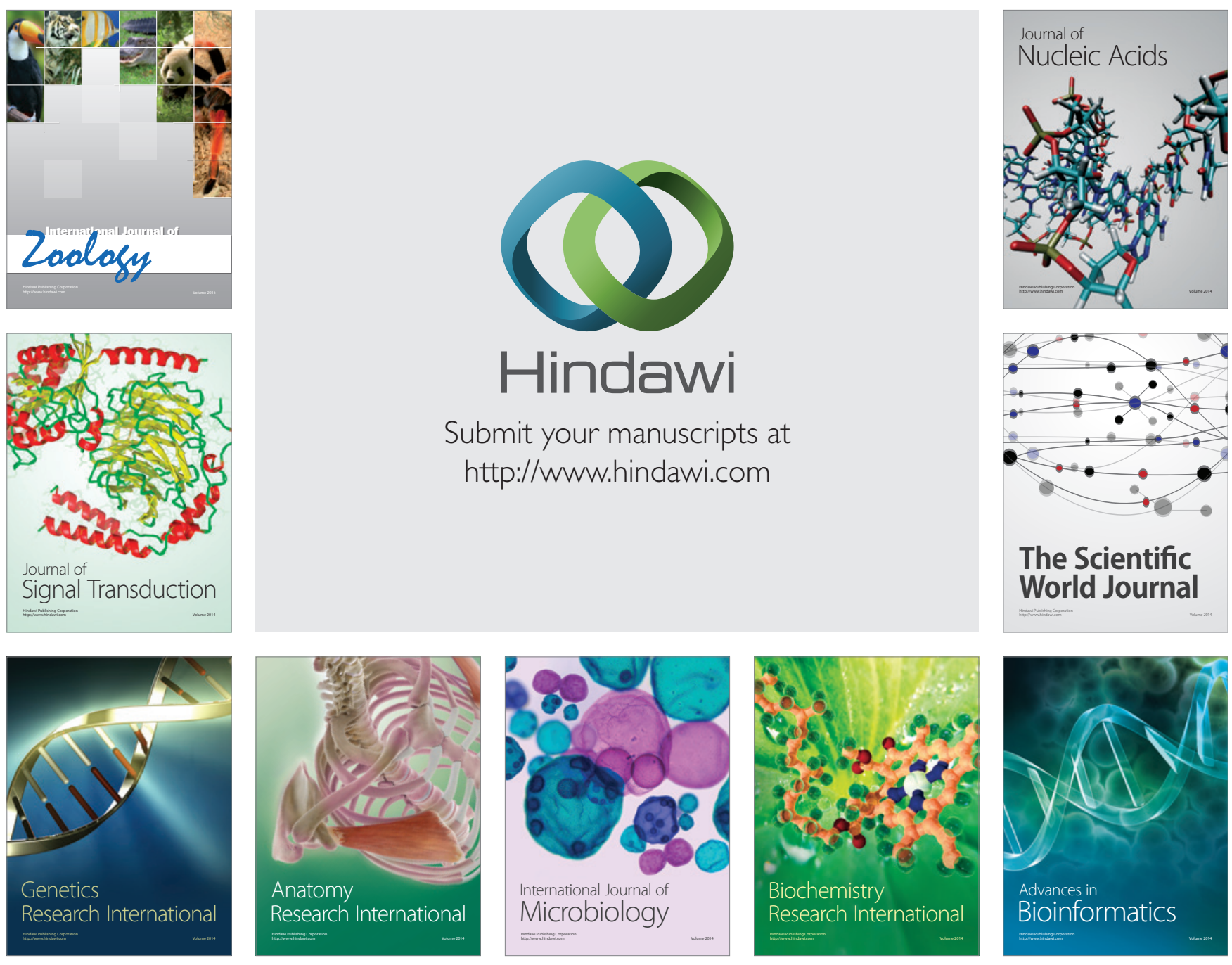

The Scientific World Journal
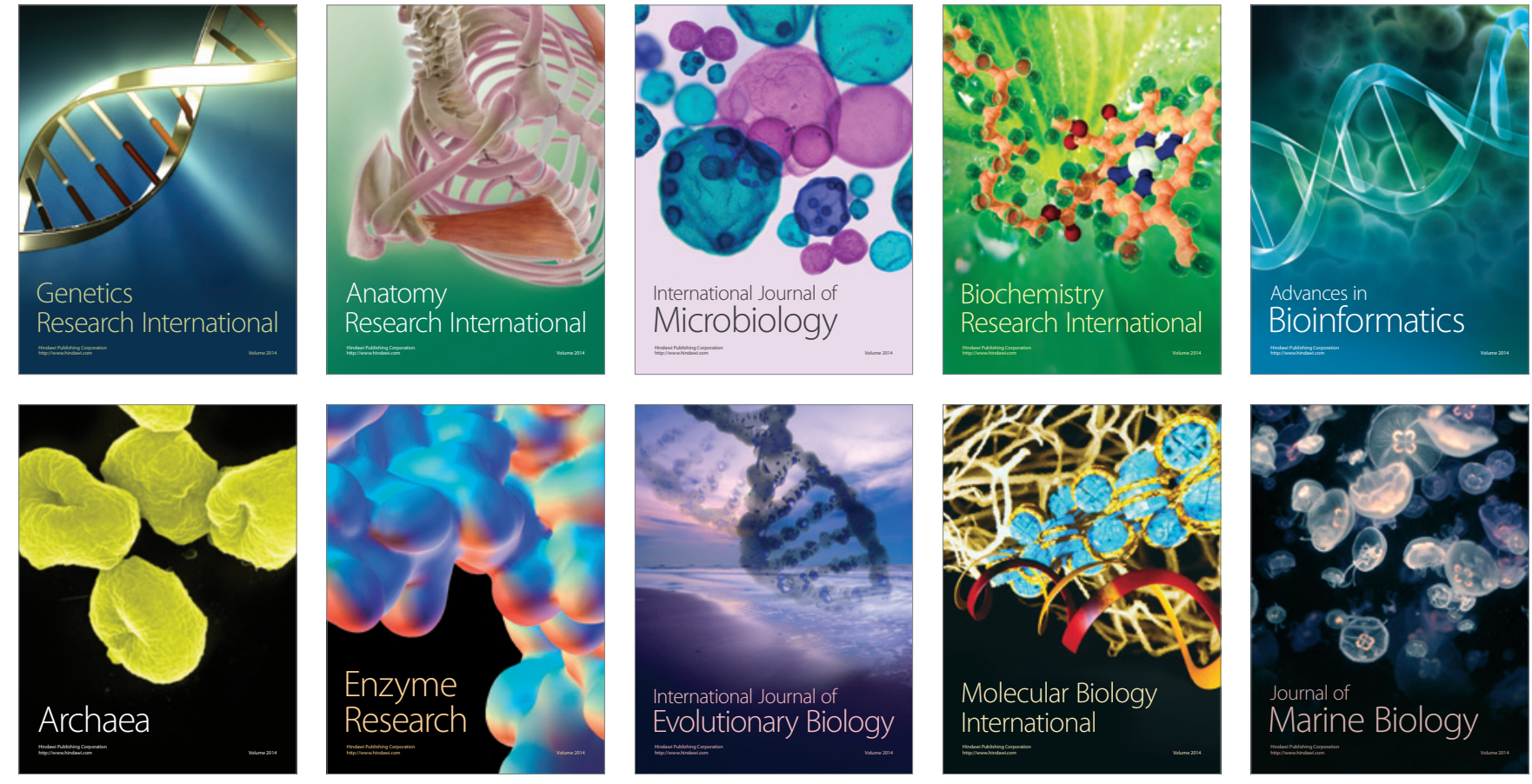